\title{
İthal Otomobil Satışlarının Döviz Kuru Esnekliği: Türkiye Üzerine Bir Uygulama*
}

\author{
Nihat IŞIK ${ }^{1}$, Suat Serhat YILMAZ ${ }^{2}$, Efe Can KILINÇ ${ }^{3}$ \\ ${ }^{1}$ Kırıkkale Üniversitesi, İktisadi ve İdari Bilimler Fakültesi, Ekonometri Bölümü, nihatis@ hotmail.com \\ ${ }^{2}$ Kırıkkale Üniversitesi, İktisadi ve İdari Bilimler Fakültesi, Ekonometri Bölümü, suatserhatyilmaz@gmail.com \\ ${ }^{3}$ Kirıkkale Üniversitesi, İktisadi ve İdari Bilimler Fakültesi, Ekonometri Bölümü, kilinc_efe@ hotmail.com
}

\section{Özet}

Otomotiv sektörü, ülke ekonomilerine birçok açıdan katkı yapmakta olup, bu konuda ilk akla gelen alanlar; dış ticaret, istihdam düzeyi, teknoloji ve rekabet düzeyleridir. Sürekli olarak cari açık problemi ile karşılaşan ülkeler de bu sektördeki gelişmeleri yakından takip etmektedirler. Bu bağlamda bu sektöre yönelik talebin bileșenlerinin belirlenmesi ülkeler açısından kritik önem taşımaktadır. Buradan yola çıkarak, bu çalışmada; bu bileșenlerden biri olan döviz kurları ile ithal perakende otomobil satışları arasındaki ilişki incelenmiştir. Bu ilişsinin incelemesinde, Tam Değiştirilmiş En Küçük Kareler, Kanonik Eşbütünleşme Regresyonu ve Dinamik En Küçük Kareler yöntemlerinden faydalanılmıştır. Bu amaçla, 2011M1-2016M2 dönemine ait aylık verilerden yararlanılmıș ve bu ilișkinin uzun dönem katsayıları tahmin edilmiștir. Her üç tahminciden elde edilen analiz sonuçları, ithal perakende otomobil satışlarının döviz kuru esneklik katsayısının teorik beklentilere uygun olarak esnek (|e $>1 \mid)$ olduğunu göstermektedir.

Anahtar kelimeler: İthal Otomobil Satışları, Döviz Kuru Esnekliği, Zaman Serisi Analizi.

\section{The Exchange Rate Elasticity of Imported Automobile Sales: An Application on Turkey Abstract}

The automotive sector has contributed in many ways to the country's economy, and the first areas that come to mind are; foreign trade, employment level, technology and competition levels. Countries that are exposed continuously to the problem of current account deficit also follow the developments closely in this sector. In this context, the determination of the components of demand towards this sector is critical in terms of countries. From this way, in this study; the relationship between exchange rates, which are one of these components, and imported retail car sales are examined. In the study of this relationship, the Modified Least Squares, Canonical Cointegration Regression and Dynamic Least Squares methods are utilized from. For this purpose, monthly data for the period 2011M1-2016M2 are used and long-term coefficients of this relationship are estimated. The analysis results obtained from each of three estimators show that the exchange elasticity coefficient of imported automobile sales is elastic $(|e>1|)$ in line with theoretical expectations.

Keywords: Imported Automobile Sales, Exchange Rate Elasticity, Time-Series Analysis.

*Bu makale, 2-4 Haziran 2016 tarihleri arasında Cumhuriyet Üniversitesi tarafından düzenlenen 17'nci Uluslararası Ekonometri, Yöneylem ve İstatistik Sempozyumunda sunulan bildirinin revize edilmiş halidir.

\section{Giriş}

Dünya nüfusu hızla artmaktadır. $\mathrm{Bu}$ nüfus artışı; ulaştırma, lojistik ve taşımacılık alanlarında büyük bir talebi de beraberinde getirmiştir. Artan talep, dünya otomotiv pazarının giderek büyümesine yol açmıştır. 2009 yılına gelindiğinde ise, bu artış küresel krizle birlikte sekteye uğramış, dünya genelinde ülkelerin üretimleri ve gelirlerinde azalma meydana gelmiştir. $\mathrm{Bu}$ azalma, olumsuz yansımalarını otomotiv sektöründe de göstererek, bu sektöre yönelik toplam talebin ve sektördeki üretimin düşmesine yol açmıştır. Kriz yıllarından sonra, Avrupa'da canlanan taleple birlikte, bu sektörde toparlanma meydana gelmiş, 2015 yılının ikinci çeyrek verilerine göre dünya otomotiv sektörü toplamda $\% 1,4$ büyümüştür. Bu büyüme, özel otomobiller düzeyinde $\% 2,4$ düzeyinde gerçekleşmiştir. Ülkemiz açısından bakıldığında ise, 2015 yılında bu sektör, Türkiye'nin 17,4 milyar dolar ihracat değeri ile toplam ihracatının \%12'sini ve 17,5 milyar dolar ithalat değeri ile toplam ithalatının \%8,5'ini oluşturmuştur. $\mathrm{Bu}$ veriler, bu sektörün hem dünya hem de Türkiye düzeyinde ekonomik açından önemini gözler önüne sermektedir (OSD, 2016b: 2).

Ülkelerin yolcu ve yük taşıma gereksinimlerini karşılamaya yönelik olan kara yolu taşıtlarını içeren otomotiv sektörü, teknolojik birikim ve alt yapı gibi diğer sektörlere sağladığı pozitif dışsallıklar açısından öncü ve stratejik bir sektördür. Bunun yanında, farklı gelişmişlik düzeylerinde olan ülkeler bakımından bu sektör farklı görevleri yerine getirmektedir. Örneğin, az gelişmiş ülkeler için bu sektör; dışa bağımlılı̆ğ azaltma, istihdam yaratma ve teknolojik yetersizlikler ve alt yapı sorunları ile baş etmede stratejik bir önem taşırken, gelişmiş ülkelere gelindiğinde ise; teknolojik birikim, alt yapı olanakları yaratma ve ihracat potansiyelini yükseltme gibi görevleri yerine getirmektedir (Eken ve Çiçek, 2009: 62). Hükümetler ve politika yapıcılar açısından bakıldığında ise, ulusal derecede otomobil talebinin ileşenlerinin belirlenmesi ve bu bileşenlerin otomobil talebi üzerindeki etkileri, geleceğe yönelik ulusal gelir tahminlerinde ve enerji gerekliliklerinin belirlenmesinde öngörü sağlamaktadır (Abu-Eisheh ve Mannering, 2002: 311). Özellikle az gelişmiş ülkelerde hızlı artan otomobil talebi, gerek şehir planlamacıları gerekse trafik mühendisleri açısından konuyu daha da önemli hale getirmektedir. Diğer taraftan Türkiye özelinde, ithal otomobil satışlarının cari açığın önemli bir belirleyicisi olması ve son dönemlerdeki döviz kuru oynaklığı bu ilişkinin incelenmesinin gerekliliğini ortaya koymuştur. $\mathrm{Bu}$ amaçla bu çalışmada, otomobil talebinin belirleyicilerinden biri olan döviz kurlarının bu talep üzerindeki etkisi incelenmiştir. Bu ilişkinin incelemesinde, Tam Değiştirilmiş En Küçük Kareler, Kanonik Eşbütünleşme Regresyonu ve Dinamik En Küçük Kareler yöntemlerinden faydalanılmıştır. Bu amaçla, 2011M1-2016M2 dönemine ait aylık verilerden yararlanılmış ve bu ilişkinin uzun dönem katsayıları tahmin edilmiştir. Literatürdeki çalışmalardan farklı olarak, "genel" otomobil talep fonksiyonunun tahmini yerine, "ithal" perakende otomobil talebine odaklanılmıştır. 
Ayrıca, tahmin yöntemi itibariyle de diğer çalışmalardan farklılaşmaya çalışılmıştır.

Çalışmanın bundan sonraki kısmı şu şekilde tasarlanmıştır: İlk olarak iktisat teorisine atıf yapılarak ithal otomobil satışlarını etkilemesi beklenen ve literatürde bu talebi açıklamaya yönelik olarak kullanılan/kullanılabilecek değişkenlere değinilmektedir. Ardından bu konuyla ilgili literatürde yapılmış önemli çalışmalar kronolojik olarak gözden geçirilmektedir. Üçüncü bölümde ise; analizlerde kullanılan veri setlerine ilişkin bilgiler, şekiller ve yorumlar bulunmaktadır. Dördüncü bölümde çalışmada kullanılan model ve yöntem açıklanmakta, beşinci bölümde ise analizlere ve bulgulara yer verilmektedir. Sonuç bölümünde ise yapılan analiz ve bulgulardan yola çıkarak değerlendirme yapilmaktadir.

\section{Otomobil Talebinin Belirleyicileri}

Dayanıklı bir tüketim malı olan otomobil talebini etkileyen birçok faktör bulunmaktadır. Bu faktörler; genel, ikâme ve tamamlayıcı faktörler biçiminde Tablo 1'de sıralanmıştır.

Tablo 1. Otomobil Talebini Etkileyen Faktörler

\begin{tabular}{lclc}
\hline Genel Faktörler & Etki & İkâmeler & Etki \\
\hline Kişi Başı Gelir & $(+)$ & Bina Satışları & $(-)$ \\
\hline Reel Faiz Oranları & $(-)$ & Motosiklet Fiy. & $(+)$ \\
\hline Enflasyon & $(-)$ & Beyaz Eşya Satı̧. & $(-)$ \\
\hline Taşıt Kr. Uyg. Faiz Or. & $(-)$ & Tamamlayıcılar & \\
\hline Kalite Artışı, Markalar & $(+)$ & $\begin{array}{l}\text { Araç. Tam. ve } \\
\text { Bak.Öd. Üc. }\end{array}$ & $(-)$ \\
\hline Özel Tüketim Vergileri & $(-)$ & Benzin Fiyatları & $(-)$ \\
\hline Döviz Kuru & $(-)$ & Mazot Fiyatları & $(-)$ \\
\hline Demografik Etkenler & $(+,-)$ & Araç Yed. Par. ve & $(-)$ \\
\hline Evlenenlerin Sayısı. Fiy. & $(+)$ & Motor Yağ.Fiyat. & $(-)$ \\
\hline Nüfus Artış1 & $(+)$ & Petrol Fiyatları & $(-)$ \\
\hline Üniversite Mez. Sayısı & $(+)$ & Karayol. Iyileș. & $(+)$ \\
\hline Küresel ve Ekon.İst. & $(+)$ & & \\
\hline Piy. Mevcut Araç Say. & $(-)$ & & \\
\hline
\end{tabular}

Kaynak: Yazarlar tarafindan oluşturulmuştur.

Tablodaki genel faktörler incelendiğinde; kişi başı gelirin, kalite artışının ve markanın, evlenenlerin sayısının, nüfus artışının, üniversite mezunlarının sayısının ve küresel ve ekonomik istikrarda meydana gelen artışların otomobil talebi üzerinde pozitif bir etkiye sahip olduğu görülmektedir. Aynı şekilde, otomobilin bir dayanıklı tüketim malı olması sebebiyle; piyasadaki mevcut araç sayısının, döviz kurunun, özel tüketim vergilerinin, taşıt kredilerine uygulanan faiz oranlarının, enflasyon ve reel faiz oranlarındaki artışların otomobil talebi üzerinde negatif anlamda etkili olabileceği beklenmektedir. Diğer taraftan, onun ikâmesi olan bina ve beyaz eşya satışlarının artışı otomobil talebini negatif, motosiklet fiyatlarının artması ise pozitif yönde etkilemektedir. Otomobile tamamlayıcı mal olarak düşünebilecek faktörlere bakıldığında ise; araçların tamirine ve bakımına ödenen ücretler, benzin fiyatları, mazot fiyatları, araç yedek parça ve ekipman fiyatları, motor yedek parça ve ekipman fiyatları ve petrol fiyatlarında meydana gelen artışların otomobil talebi üzerinde negatif, karayollarındaki iyileşmelerin ise otomobil talebi üzerinde pozitif bir etkiye sahip olacağı beklenmektedir.

Türkiye'de otomobil piyasasının gelişimi dikkate alındığında, 1990'lı yıllarda yerli otomobil satışlarının ithal otomobil satışlarından daha fazla olduğu görülmektedir. $\mathrm{Bu}$ yıllarda otomobil üretiminin büyük bir bölümü Fiat-Tofaş ve Oyak Renault girişimleri tarafından yapılmıştır. İlerleyen yıllarda, özellikle 2000 yılından sonra krizlerin etkisiyle gerek yerli gerekse de toplam otomobil satışlarının ve üretimlerinin önemli ölçüde düştüğü gözlenmiştir. 2004 yılından itibaren otomobil satışları tekrar yükselişe geçmiş, bu durum 2008 Küresel Finans Krizi'ne kadar devam etmiştir. Otomobil ihracatı 1997-2008 yılına kadar sürekli artış kaydetmiş, 2009 yılında bir önceki yıla göre yaklaşık olarak \%30 oranında azalmış, akabinde 2010 ve 2011 yıllarında tekrar artış gözlenmiştir. 2016 yılı itibariyle gelinen noktada, üretilen otomobillerin yaklaşık olarak \%75'inin ihraç edildiği, dolayısıyla yerli otomobil ihtiyacının önemli ölçüde $(\% 75$ 'i) ithal otomobillerle karşılandığı görülmüştür (Bkz. Tablo 2).

Tablo 2. Türkiye'de Otomobil Sektörü Gelişimi

\begin{tabular}{cccccc}
\hline Yıl. & $\begin{array}{c}\text { Yerli } \\
\text { Otomobil } \\
\text { Satışı }\end{array}$ & $\begin{array}{c}\text { İthal } \\
\text { Otomobil } \\
\text { Satışı }\end{array}$ & $\begin{array}{c}\text { Toplam } \\
\text { Otomobil } \\
\text { Satışı }\end{array}$ & İhracat & Üretim \\
\hline 1996 & 182.239 & 57.479 & 239.718 & 39.252 & 325.460 \\
1997 & 219.810 & 125.025 & 344.835 & 31.174 & 399.923 \\
1998 & 204.054 & 111.536 & 315.590 & 37.926 & 405.001 \\
1999 & 157.452 & 131.215 & 288.667 & 92.051 & 325.291 \\
2000 & 207.739 & 258.987 & 466.726 & 104.744 & 468.381 \\
2001 & 59.179 & 72.259 & 131.438 & 202.158 & 285.737 \\
2002 & 35.519 & 55.096 & 90.615 & 261.934 & 357.217 \\
2003 & 73.267 & 153.769 & 227.036 & 358.745 & 562.466 \\
2004 & 139.541 & 311.668 & 451.209 & 518.595 & 862.035 \\
2005 & 136.708 & 301.889 & 438.597 & 561.078 & 914.359 \\
2006 & 117.725 & 255.494 & 373.219 & 706.402 & 1.024 .987 \\
2007 & 120.740 & 236.725 & 357.465 & 829.879 & 1.132 .951 \\
2008 & 99.205 & 206.793 & 305.998 & 920.763 & 1.171 .917 \\
2009 & 126.277 & 243.542 & 369.819 & 637.855 & 884.466 \\
2010 & 155.634 & 354.150 & 509.784 & 763.670 & 1.124 .982 \\
2011 & 179.488 & 414.031 & 593.519 & 801.112 & 1.234 .637 \\
2012 & 146.604 & 409.676 & 556.280 & 745.354 & 1.115 .233 \\
2013 & 147.128 & 517.527 & 664.655 & 843.467 & 1.166 .043 \\
2014 & 157.349 & 429.982 & 587.331 & 902.194 & 1.218 .848 \\
2015 & 187.881 & 537.715 & 725.596 & 1.007 .267 & 1.410 .034 \\
2016 & 191.893 & 565.045 & 756.938 & 1.155 .033 & 1.536 .673 \\
\hline
\end{tabular}

Kaynak: ODD, www.odd.org,Erişim Tarihi: 28.11.2017.

$\mathrm{Bu}$ çalışmada, bu faktörlerden yalnızca biri olan döviz kurlarının genel ithal otomobil satışları üzerindeki etkisi Türkiye özelinde incelenmektedir. $\mathrm{Bu}$ noktada dikkat çekilmesi gereken önemli bir husus, çalışmada genel otomobil talep fonksiyonu yerine ithal otomobil talebi üzerinde döviz kurlarının etkisinin belirlenmesidir. Analizler sonucunda, döviz kurlarındaki artışların ithal perakende otomobil fiyatlarını doğrudan etkileyerek uzun dönemde bu talep üzerinde negatif olarak etkili olması, diğer taraftan, otomobilin zorunlu mal olmaması sebebiyle elde edilen esneklik katsayısının ise birden büyük yani esnek olması beklenmektedir.

\section{Literatür Taraması}

Konunun önemi dikkate alındığında gerek dünyada gerekse Türkiye'de bu alanda yapılmış birçok çalışma göze çarpmaktadır. Fakat genel olarak literatürde otomobil genel talep fonksiyonunun tahmini ve çeşitli faktörlerin bu talep üzerindeki etkileri araştırılırken, doğrudan ithal perakende otomobil talebini belirlemeye yönelik bir çalışmaya rastlanmamıştır. İthal otomobil satışlarının cari açığın önemli bir belirleyicisi olması ve son dönemlerdeki döviz kuru oynaklığı, bu ilişkinin incelenmesinin temel motivasyonu olmuştur. Bunun Türkiye özelinde sebebi Otomotiv Sanayicileri Derneği (ODD)'nin bu verileri aylık olarak 2011 yılından itibaren yayınlamaya başlamış olmasıdır. $\mathrm{Bu}$ 
anlamda bu çalışmanın, gerek kullanılan veri seti, gerekse ithal otomobil talep fonksiyonunda uzun dönem ilişkinin katsayılarının tahmininde kullanılan yöntemler bakımından literatüre katkı sağlayacağı düşünülmektedir.

$\mathrm{Bu}$ kısımda otomobil talebini ele alan ve bu çalışma ile doğrudan ilgili olduğu düşünülen çalışmaların bulguları kronolojik biçimde verilmektedir:

Madden (1998), 1973-1982 dönemini kapsayan çeyreklik verileri kullanarak Avusturalya'daki yolcu otomobillerinin talebini araştırdığı çalışmada, araçları küçük, orta ve lüks olmak üzere üç gruba ayırarak ele alınan dönem içerisindeki popülaritesini incelemiştir. Çalışma sonucunda, küçük araçların ilgili dönem içinde popülaritesinin yükseldiğini, orta araçların ise yakıt tüketimindeki etkinsizliği nedeniyle popülaritesinin azaldığını tespit etmiştir. Ayrıca, hükümetin petrole oranlı fiyatlama politikasının bütün sınıflarda otomobil talebini azalttığı sonucuna varmıştır.

Alper ve Serdar (2000), Türkiye otomobil piyasasının 1996-1999 yılları arasındaki görünümünü inceledikleri çalışmalarında, otomobil talep fonksiyonunu tahmin etmişlerdir. Bu süreçte 20 ayrı marka ve modele ait aylık; fiyat, satış, kalite, teknik özellikler ve faiz gibi çeşit makroekonomik değişkenlerin otomobil talebi üzerinde etkisini incelemişlerdir. $\mathrm{AB}$ menşeili otomobiller için talebin fiyata göre esnek olmadığı, diğer ülkelerden ithal edilen otomobiller için ise esnek olduğu bulgusuna ulaşmışlardır.

Alper ve Serdar (2007), 1996 ve 1999 dönemini kapsayan çeyreklik verilerden yararlandıkları çalışmalarında, GLS yöntemi ile otomobilin; menşei, fiyatı, miktarı, kalitesi, yeni ürün özellikleri ve çeşitli makroekonomik değişkenler ile otomobil satışları arasındaki ilişkiyi incelemişlerdir. Analiz sonuçları kalite ve menşeinin otomobil talebi üzerinde etkili olduğuna işaret etmektedir. Ayrıca, çalışmanın sonuçları diğer ülkeler için yapılmış çalışmalarla tutarlı olarak Avrupa ve Avrupa kökenli yeni satın alımlar için otomobil talebinin, Türkiye'de kısa ve uzun dönemde kalite açısından esnek olduğunu göstermektedir.

Ebu-Aiesheh ve Mannering (2002), 1971-1998 dönemi yıllık verilerini kullanarak Batı Şeria'da Filistin topraklarına ait veriler ile; nüfusun, istihdamın, ekonomik büyümenin, petrol fiyatlarının, döviz kurlarının ve otomobil ithalatına yönelik hükümet politikalarının otomobil talebi üzerindeki etkisini Eşanlı Denklem Modelleri ve Üç Aşamalı En Küçük Kareler (3SLS) yöntemleriyle incelemişlerdir. Elde ettikleri bulgular, otomobil sahipliğindeki artışların ve büyümenin büyük bir bölümünün Gayri Safi Yurtiçi Hasıla (GSYH)'ya bağlı olarak geliştiğini göstermektedir. Ayrıca, hükümet politikaları otomobil sahipliğinin büyümesinde önemli bir rol oynamaktadır.

Bülbül ve Orkunoğlu (2009)'da 2008 ve 2009 yıllarında yapılan özel tüketim vergisi indirimlerinin firma, galeri ve plazalar tarafından tüketicilere yansitılıp yansıtılmadığı araştırılmıştır. Yaptıkları değerlendirmeler sonucunda, yapılan özel tüketim vergisi indirimlerinin fiyatlara yansımadığını ve ileriye dönük ekonomi politikalarında; Maliye Bakanlı̆̆ı, Sanayi ve Ticaret Bakanlı̆̆ 1 ve sivil toplum kuruluşlarının birbirleri ile iletişim içinde hareket etmeleri ve karar vermelerinin gerekliliğini vurgulamışlardır.

Eken ve Çiçek (2009) uyguladıkları anket çalışması sonucunda kredilerin otomobil satışları üzerinde pozitif bir etkisi olduğu sonucuna ulaşmışlardır. Ayrıca, 2009 yılında meydana gelen kredi hacmi artışlarının otomobil satışlarını yükselttiğini tespit etmişlerdir.

Özçam ve Özçam (2012), 1965 ve 1975 yılları arasındaki verilerden yola çıkarak, Amerika Birleşik Devletleri otomobil talebini Çok Denklemli Ayrıştırma Yaklaşımı ve Eşanlı Denklem Modelleri yaklaşımları çerçevesinde incelemişlerdir. $\mathrm{Bu}$ amaçla; Görünüşte İlişkisiz Regresyon (SUR), Yuvalanmış Logit (NL), Doğrusal Olmayan Üç Aşamalı En Küçük Kareler (NLTSLS) ve Genelleştirilmiş En Küçük Kareler (GLS) gibi yöntemler sonucunda elde ettikleri bulgular, Türkiye'de otomobil satın alınırken otomobillerin menşeinin tüketiciler tarafından dikkate alındığını göstermektedir.

Advalorem vergilerin Laffer etkisine bağlı olarak otomobil arz ve talep esneklikleri üzerindeki etkisini inceleyen Özçam (2014), klasik vergi yükünün geçişkenlik katsayısının tüketicilerden üreticilere geçerken azaldığını tespit etmiştir.

Özçam ve Özçam (2014) 2006 Ocak ve 2010 Aralık döneminde Türkiye için otomobil tiplerini dikkate alarak yaptıkları çalışmalarında otomobilleri ayrıştırmışlardır. Analizleri sonucunda, Türkiye'de ele alınan dönemde çeşitli araç tipleri arasında tüketicilerin tercihlerinin değiştiğini tespit etmişlerdir. Yine 2009 dönemi dikkate alındığında, piyasa fiyat esnekliklerinin piyasa arz esnekliklerinden daha az olduğu sonucuna varmışlardır. Son bölümde ise, otomobillerin tamamını dikkate alan bir yöntem olan En Küçük Kareler Kukla Değişken Modeli (LSDVM)'ni kullanarak 4 ayrı otomobil türü için ilgili dönemde fiyat esnekliklerinin değişip değişmediğini kontrol etmişlerdir. Elde ettikleri bulgular, 4 ayrıştırılmış bölüm içinde fiyat esnekliğinin ilgili dönemde aynı yönde hareket ettiğini göstermektedir.

Özçam ve Özçam (2015) Türkiye özelinde yaptıkları çalışmalarında, 2006 Ocak - 2011 Aralık ve 2006 - 2011 Eylül dönemi aylık verilerini kullanarak, 5 farklı model çerçevesinde, GSYH dalgalanmaları ile otomobil talebi arasındaki ilişkiyi incelemişlerdir. $\mathrm{Bu}$ değişkenler arasında yüksek bir ilişki tespit eden yazarlar, çalışmanın diğer bölümünde ise, çeşitli fiyat, gelir ve döviz kuru gibi değişkenlerle, otomobil fiyatları arasındaki ilişkiyi incelemişlerdir. Analiz sonuçları Reel GSYH ve otomobil satışları arasında dikkate değer bir pozitif korelasyona işaret etmektedir. Ayrıca çalışmanın bulguları, Türkiye'de otomobil talebinin hem gelir hem de fiyat açısından esnek olduğunu, reel efektif döviz kurunun katsayısının -1,071 ve anlamsız olduğunu göstermektedir.

Genel olarak literatürde yapılmış çalışmalara bakıldığında, bu çalışmaların otomobil talebinin bütününü dikkate alan ve bu talebin fiyat ve gelir esnekliklerini tahmin etmeye çalışan çalışmalar olduğu görülmektedir. Ayrıca, bu alanda yapılmış ve burada değinilen çalışmalara ek olarak, Türkiye Ekonomi Politikaları Araştırma Vakfı (TEPAV), Otomotiv Distribütörleri Derneği (ODD) ve Otomotiv Sanayii Derneği (OSD) gibi dernek ve vakıflar tarafından hazırlanan sektör raporları ve bültenler olduğunu da vurgulamak gerekir. 


\section{Veri Setleri}

Çalışmada kullanılan değişkenler aşağıdaki tabloda yer almaktadır. Veri setleri 2011-Ocak ve 2016-Şubat arası dönemi kapsamakta olup aylık frekanstadır. İthal perakende otomobil satışları verileri Otomotiv Distribütörleri Derneği (ODD)'nin internet sitesinden, döviz kuru verileri ise Türkiye Cumhuriyet Merkez Bankası'nın Elektronik Veri Dağıtım Sistemi (EVDS)'nden elde edilmiştir. Bu bölümde, çalışmada yer alan veri setlerinde incelenen dönemde meydana gelen gelişmeler kısaca ele alınacaktır.

Tablo 3. Veri Setleri

\begin{tabular}{|c|c|}
\hline Değiş. & Değişkenin Tanımı \\
\hline İth: & $\begin{array}{l}\text { Bu değişken toplam ithal perakende otomobil } \\
\text { satışlarının sayısını ifade etmektedir. Uygulama }\end{array}$ \\
\hline $\begin{array}{l}\text { Otomobil Satışları* } \\
\text { (LNOTOSA) }\end{array}$ & $\begin{array}{l}\text { kısmında değişkenin mevsimsellikten } \\
\text { arındırılmış ve logaritması alınmış hali } \\
\text { kullanılmıştır. }\end{array}$ \\
\hline $\begin{array}{l}\text { Sepet Döviz Kuru** } \\
\text { (LNSEPETSA) }\end{array}$ & 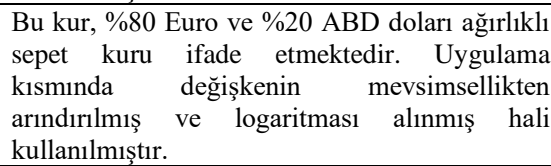 \\
\hline
\end{tabular}

Kaynaklar: * ODD, www.odd.org,Erișim Tarihi: 28.03.2016.

** TCMB, www.tcmb.org, Erişim Tarihi: 28.03.2016.

\subsection{Sepet Kur}

OSD verilerine göre, Avrupa Birliği (AB)'nden ithal edilen otomobil sayıları Türkiye'nin toplam otomobil ithalatının yaklaşık \%81'ini oluşturmaktadır (OSD, 2016a: 3). Bunun başlica nedenlerinden biri olarak $\mathrm{AB}$ ile olan gümrük birliği anlaşması çerçevesinde otomobillerin Türkiye'ye vergisiz girişi sayılabilmektedir. Bu bağlamda, bu çalışmada AB'nin ithal otomobil satış sayılarındaki yoğunluğu dikkate alınarak \%80'i Euro ve \%20'si ABD doları ağırlıklı olmak üzere bir sepet kur oluşturulmuştur. Şekil 1'de, Euro'nun, ABD Dolarının ve oluşturulan sepet kurunun incelenen dönem içerisindeki hareketleri gösterilmiştir.

Genel olarak bakıldığında, her iki döviz kurunun da yükselen bir trend gösterdiği görülmektedir. Yine yıllar bazında bakıldığında özellikle 7 ve 11. aylar arasında sistematik bir yükselme olduğu göze çarpmaktadır. Bu gözlemlerden yola çıkarak, döviz kuru değişkeninin hem mevsimsel etki hem trend etkisi altında olduğu söylenebilir.

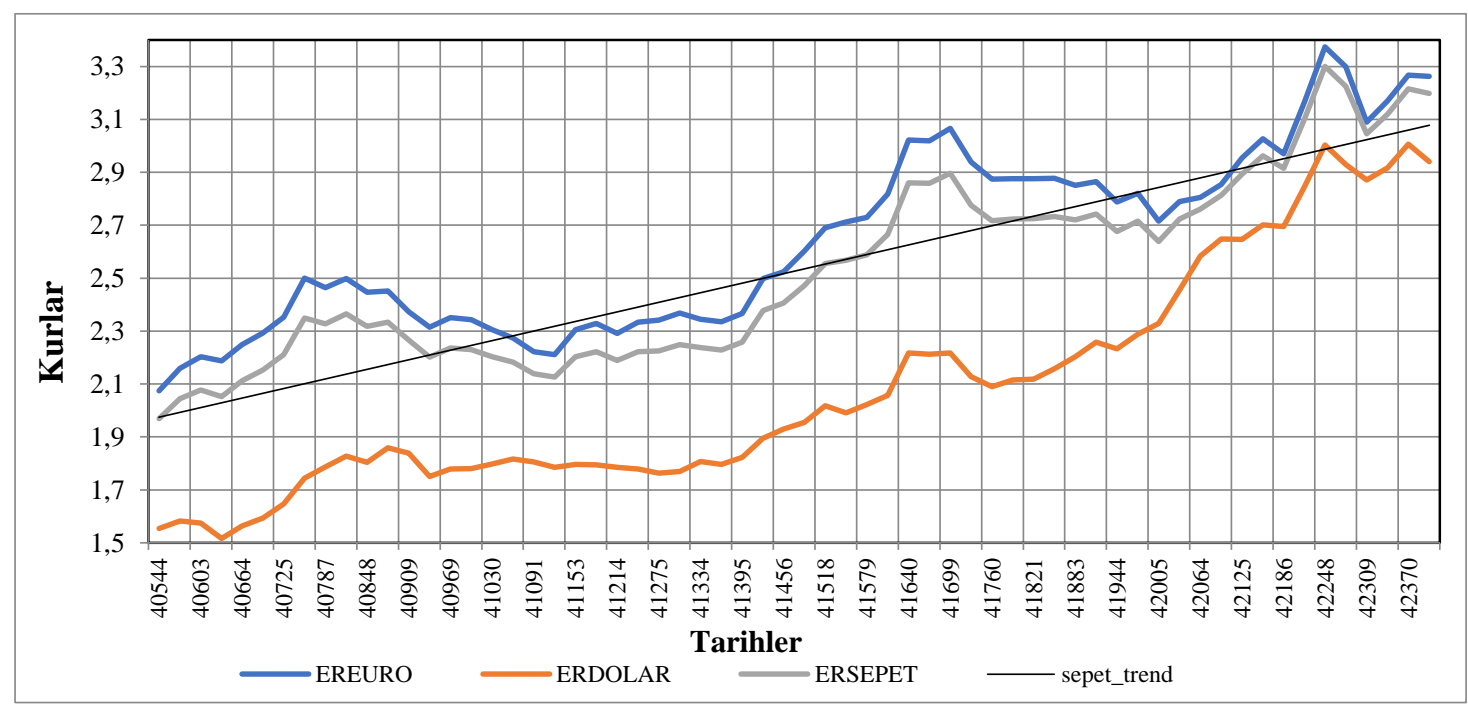

Kaynak: TCMB, EVDS. www.tcmb.gov.tr (Erişim Tarihi: 28.03.2016)

Şekil 1. Döviz Kurları ve Sepet Kur

Ayrıca çalışmada, ithal perakende otomobil satışlarının talebinin belirlenmesinde nominal kurlar üzerinden hesaplanan sepet kur kullanılmıştır. Böyle bir kullanımın birkaç nedeni bulunmaktadır. Birincisi, ithal perakende otomobil satışlarının talebinin belirlenmesinde, tüketicilerin reel kuru düşünerek ya da hesaplayarak otomobil aldıklarını varsaymak yerine, nominal, yani "gösterge kur üzerinden" satın alma kararı verdiklerini kabul etmenin tüketicilerin davranışlarını açıklamada daha uygun olacağının düşünülmesidir. İkinci neden ise, gerek Euro'nun gerekse ABD dolarının enflasyon etkisinden arındırılmasında, o ülke ya da ülke gruplarının fiyat düzeylerinin Türkiye'deki iç fiyat düzeylerine oranının kullanılmasının ortaya çıkardığ 1 durumla ilgilidir. Örneğin, AB enflasyon oranı, birliğe üye olan tüm ülkelerin ortalama fiyat düzeyinin genel eğilimini göstermekte iken, Türkiye sadece AB'deki birkaç ülkeden yoğun olarak otomobil ithal etmektedir. Bu durum otomobil fiyat artışlarının enflasyondan arındırılmasını zorlaştırmaktadır. Diğer taraftan ekonometrik tahminler yapılırken, enflasyon etkisinden arındırılmış kurlar üzerinden yapılan analizlerin katsayılarının teorik beklentilere ters ve anlamsız sonuçlar verdiği görülmüştür. Bu nedenlerden ötürü çalışmada nominal kurlar açıklayıcı faktör olarak seçilmiştir.

\section{2. İthal Perakende Otomobil Satışları}

2008-2009 Küresel Finans Krizi hem ABD hem de AB ülkelerinde birçok büyük otomotiv firmasının üretimini geçici olarak azaltmış, hatta durdurma durumuna getirmiştir. Bu daralma ile birlikte bu sektörde çok büyük işçi çıkarımları meydana gelmiştir (TEPAV, 2013: 11-12). Fakat o yıllardan sonra gerek Avrupa gerekse dünya ekonomisindeki iyileşmeler bu sektör için tekrar artış eğilimini beraberinde getirmiştir. Şekil 2, ilgili sektörde meydana gelen ithal otomobil satı̧s sayılarını ve artış trendini göstermektedir. Şekil 2'ye bakıldığında, ithal perakende otomobil satış 
sayılarının incelenen dönem içerisinde aylık ortalama 33000'lerden 44000'lere geldiği görülmektedir. Dolayısıyla, bu değişkenin trend etkisi içerdiği söylenebilir. Mevsimselliğe bakıldığında ise, her yılın son ayında otomobil satışlarında bir yükseliş olduğu görülmektedir. $\mathrm{Bu}$ yükselişin sebebi olarak; yeni yıla yaklaşıldığında galericilerin eski modelleri ellerinden çıkarabilmek için otomobil fiyatlarına ilişkin kampanya yapmaları, Özel Tüketim Vergisi (ÖTV) ile ilgili beklentiler ve yıl sonuna yaklaşıldığında ilgili taşıt kredilerine ilişkin kampanyaların gerçekleşmesi gibi nedenler gösterilebilir.

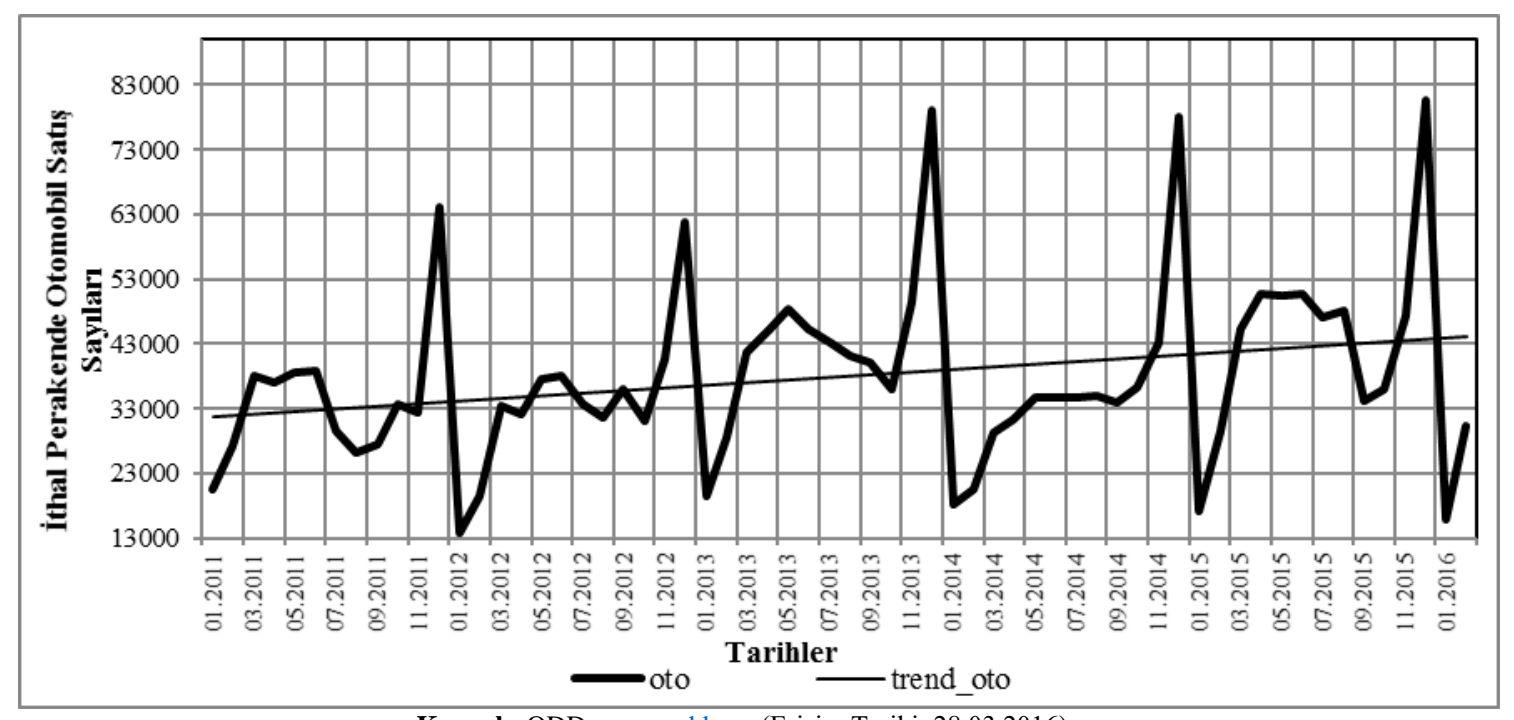

Kaynak: ODD, www.odd.org (Erişim Tarihi: 28.03.2016)

Şekil 2. İthal Perakende Otomobil Satışları

Her iki değişkenin de hem trend hem de mevsimsel etki altında olduğu tespit edildikten sonra, Şekil 3'te, çalışmaya ilişkin verilerin TRAMO/SEATS yöntemi ile mevsimsellikten arındırılmış ve doğal logaritması alınmış halleri gösterilmiştir. Şekle bakıldığında, LNSEPETSA ve
LNOTOSA değişkenlerinin negatif ilişkili oldukları görülebilmektedir. Bu gözlem, tahmin edilecek modellere ilişkin katsayıların negatif olacağına dair bir ön bilgi sağlamaktadır.

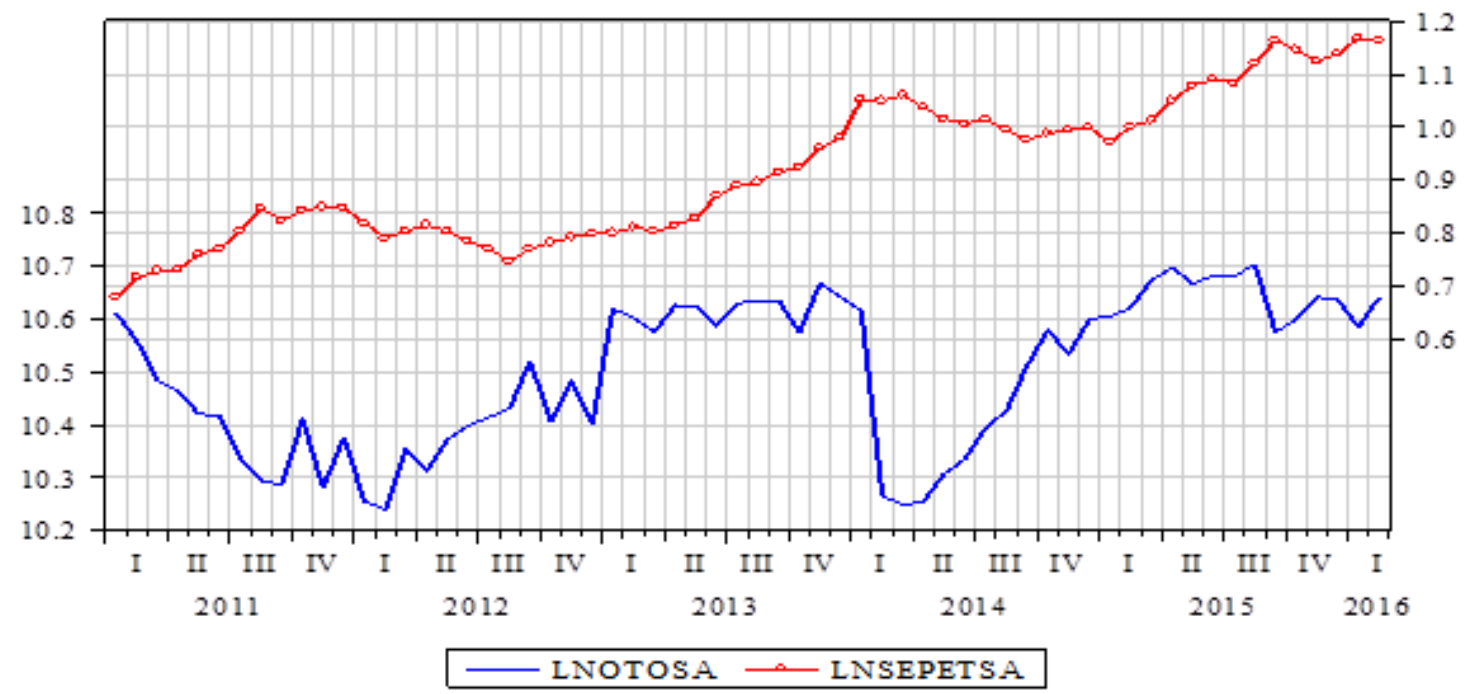

Şekil 3. İthal Perakende Otomobil Satışları ve Sepet Döviz Kuru

\section{Model ve Yöntem}

$\mathrm{Bu}$ kısımda çalışmada kullanılan ekonometrik model ve yönteme ilişkin bilgi verilecektir.

\subsection{Model}

Çalışmada kullanılan model,

LNOTOSA $_{t}=\beta_{1}+\beta_{2}(\text { LNSEPETSA })_{t}+\beta_{3}(\text { TREND })_{t}+u_{t}$ şeklindedir. Burada, LNOTOSA ve LNSEPETSA değişkenleri sırasıyla, aylık perakende ithal otomobil satışı ve sepet döviz kuru verilerinin mevsimsellikten arındırılmış ve doğal logaritması alınmış halini göstermektedir.

\subsection{Yöntem}

Değişkenlerin düzey değerleri itibariyle durağan olmayıp, aynı dereceden durağan olması durumu değişkenler arasında 
eşbütünleșik bir ilişkinin olup olmadığının incelenmesini mümkün kılmaktadır. Eşbütünleşme, durağan olmayan seriler arasındaki uzun dönemli ilişkiyi tanımlar. Uzun dönemli katsayıların sıradan en küçük kareler metoduyla tahmin edilmesi otokorelasyon ve içsellik sorunlarından dolayı yanlı sonuçlara neden olmaktadır. EKK yönteminin ortaya çıkarttığı bu problemleri aşabilmek için; Phillips ve Hansen (1990) tarafindan geliştirilen FMOLS, Park (1992) tarafindan geliştirilen CCR ve Saikkonen (1992), Stock ve Watson (1993) tarafından geliştirilen DOLS tahmincileri kullanılabilmektedir. Bu metotta, eşbütünleşik denklem ve stokastik şokların uzun dönem korelasyonunun neden olduğu sorunların üstesinden gelebilmek için, bağımsız değişkenlerle hata terimi arasındaki içsellik ilişkisinin yanı sıra hata terimleri arasındaki otokorelasyon problemi de dikkate alınmaktadır (Aktaran: Küçükaksoy ark., 2015: 706).

Phillips ve Hansen (1990) tarafindan önerilen FMOLS tahmincisi ile Park (1992) tarafından geliştirilen CCR tahmincisi, eşbütünleşik vektörler arasındaki otokorelasyonu düzeltmek ve içsellik problemini gidermek için yarıparametrik bir düzeltme yöntemi kullanmaktadır. Bu tahminciler asimptotik olarak sapmasız ve etkindir. Ayrıca, asimptotik $\chi^{2}$ istatistiksel çıkarımını kullanarak standart Wald testlerinin kullanımına imkân vermektedir (Wang ve Wu, 2012: 533). DOLS tahmin prosedürü ise bağımsız değişkenin gecikme (lags) ve öncüllerini (leads) eşbütünleşme denklemine eklemektedir (Refaei ve Morteza, 2015).

FMOLS tahmincisi şu şekilde formüle edilebilir:

$y_{t}=X_{t}^{t} \beta+D_{t}^{t} \gamma_{1}+u_{1 t}$

(1) numaralı eşitlikte $y_{t}, I(1)$ bağımlı değişkendir ve $X_{t}^{s}$ ise $X_{t}=r_{21}^{\prime}+r_{22}^{\prime}+D_{2 t}+\varepsilon_{2 t}$ ile $\Delta \varepsilon_{2 t}=u_{2 t}$ eşitlikleri tarafından açıklanan stokastik açıklayıcı değişkenleri temsil etmektedir. Diğer taraftan, $D=\left(D_{1 t}^{s}, D_{2 \mathrm{t}}^{s}\right)$ deterministik trend değişkenleridir ve $u_{1 t}$ sıfir ortalama ve kovaryanslı $(\Omega)$ hata terimidir.

tahmincisi,

$\theta_{\text {FMOLS }}=\left[\begin{array}{c}\hat{\beta} \\ \hat{y_{1}}\end{array}\right]=\left[\sum_{t=1}^{T} Z_{t} Z_{t}^{s}\right]^{-1}\left[\sum_{t=1}^{T} Z_{t} y_{t}^{+}-T\left[\begin{array}{c}\hat{\lambda}_{12} \\ 0\end{array}\right]\right]$

şeklindedir. (2) numaralı eşitlikte $Z_{t}=\left(X_{t}^{t} D_{t}^{s}\right)^{t}$ ve $y_{t}^{+}=y_{t}-\widehat{\omega}_{12} \widehat{\Omega}_{22}^{-1} \hat{u}_{2}$ dönüştürülmüş veriyi göstermektedir. $\hat{\lambda}_{12}^{+}=\hat{\omega}_{12} \widehat{\Omega}_{22}^{-1} \hat{u}_{12}, \quad u_{t}=\left(\hat{u}_{1 t}^{-1}, \hat{u}_{2 t}^{-1}\right)^{s}$ eşitliği kullanılarak tahmin edilen uzun dönem varyans-kovaryans matrisleri ve ilgili elemanlar ile tahmin edilen sapma düzeltme terimidir (Mthembu, 2015: 90-91).

CCR tahmincisi, eşbütünleşme regresyonundaki değişkenlerin dönüşümüne dayanmaktadır. Bu dönüşüm OLS tahmincisinin ikinci sıra sapmasını ortadan kaldırmaktadır. Uzun dönem kovaryans matrisi şu şekilde formüle edilebilir:

$\Omega=\lim _{n \rightarrow \infty=\frac{1}{n}} E\left(\sum_{t=1}^{n} u_{t}\right)\left(\sum_{t=1}^{n} u_{t}\right)^{n}=\left[\begin{array}{ll}\Omega_{11} & \Omega_{12} \\ \Omega_{21} & \Omega_{22}\end{array}\right]$

$\Omega$ matrisi şu şekilde de ifade edilebilir:

$\Omega=\Sigma+\Gamma+\Gamma^{s}$

$$
\begin{aligned}
& \Sigma=\lim _{n \rightarrow=x} \sum_{t=1}^{n} E\left(u_{t} u_{t}^{v}\right) \\
& \Gamma=\lim _{n \rightarrow=x} \sum_{k=1}^{n} \sum_{t=k+1}^{n} E\left(u_{t} u_{t}^{n}\right) \\
& \Lambda=\Sigma+\Gamma=\left(\Lambda_{1}, \Lambda_{2}\right)=\left[\begin{array}{ll}
\Lambda_{11} & \Lambda_{12} \\
\Lambda_{21} & \Lambda_{22}
\end{array}\right]
\end{aligned}
$$

şeklindedir. Dönüştürülmüş veriler şu şekilde elde edilebilir:

$$
\begin{aligned}
& y_{2 t}^{*}=y_{2 t}-\left(\Sigma^{-1} \Lambda_{2}\right)^{v} u_{t} \\
& y_{1 t}^{*}=y_{1 t}-\left(\Sigma^{-1} \Lambda_{2} \beta+\left(0, \Omega_{11} \Omega_{22}{ }^{-1}\right)^{v}\right)^{o} u_{t}
\end{aligned}
$$

Kanonik eşbütünleşme regresyonu şu forma dönüșür:

$y_{1 t}^{*}=\beta^{v} y_{2 t}^{*}+u_{1 t}^{*}$

$$
y_{1 t}^{*}=u_{1 t}-\Omega_{11} \Omega_{22}{ }^{-1} u_{2 t}
$$

(10) numaralı eşitlikteki OLS tahmincisi aynı zamanda asimptotik olarak ençok olabilirlik tahmincisine eşittir. (11) numaralı eşitlik dönüştürülmüş değişkenlerin $u_{1 t}$ ile $u_{2 t}$ arasındaki olası korelasyon nedeniyle meydana gelebilecek asimptotik sapmayı nasıl ortadan kaldırdığını göstermektedir (Mehmood ve Shahid, 2014: 54).

DOLS tahmincileri $u_{1 t}$ ile $u_{2 t}$ arasındaki uzun dönem korelasyonu gidermek amaciyla eşbütünleşme regresyonuna $\Delta X^{\prime}$ 'in gecikme ve öncül değerlerinin eklenmesiyle elde edilir:

$y_{t}=X_{t}^{s} \beta+D_{1 t}^{s} \gamma_{1}+\sum_{j=-q}^{g} \Delta X_{t+j}^{s} \delta+v_{1 t}$

(12) numaralı eşitlikteki OLS tahmincileri FMOLS ve CCR tahmincilerindeki ile aynı asimptotik dağılıma sahiptir (Wang ve Wu, 2012: 534).

\section{Bulgular}

Çalışmada kullanılan seriler öncelikle mevsim etkisinden arındırılmış, ardından güvenilir sonuçların elde edilebilmesi için serilerin durağanlık mertebeleri araştırılmış ve eşbütünleşme analizi için en uygun gecikme uzunluğu Vektör Otoregresif Model (Vector Auto Regressive-VAR) kullanılarak belirlenmiştir. Serilerin eşbütünleşik olduklarının belirlenmesinin ardından FMOLS, DOLS ve CCR yöntemleri ile değişkenler arasındaki uzun dönem ilişkinin katsayıları elde edilmiştir. Son olarak seriler arasındaki nedensellik ilişkisi araştırılmıştır.

Zaman serilerinde durağanlık, herhangi bir zaman serisi değişkeninin zamana bağlı olarak ortalamasının ve varyansının sabit olması ve gecikme seviyesine bağlı kovaryansa sahip olması ile ifade edilmektedir. Serilerin durağanlıkları Augmented Dickey-Fuller (ADF) (1981) ve Phillips Perrons (PP) (1988) birim kök testleri kullanılarak test edilmiştir. ADF'de standart DF'den farklı olarak hata teriminde otokorelasyon sorununu ortadan kaldırmak için bağımlı değişkene ait gecikmeli değerler bağımsız değişken olarak modele eklenmektedir (Durkaya ve Ceylan, 2006: 84). $\mathrm{Bu}$ çalışmada ADF gecikme uzunluğunun belirlenmesinde Schwarz bilgi kriteri dikkate alınmıştır.

(4) numaralı eşitlikte, 
Tablo 4. Birim Kök Testi Sonuçları

\begin{tabular}{lcccc}
\hline \multirow{2}{*}{ Değişkenler } & \multicolumn{2}{c}{ ADF } & \multicolumn{2}{c}{ PP } \\
\cline { 2 - 5 } & Sabitli & $\begin{array}{l}\text { Sabitli- } \\
\text { Trendli }\end{array}$ & Sabitli & $\begin{array}{c}\text { Sabitli- } \\
\text { Trendli }\end{array}$ \\
\hline LNOTOSA & -2.165282 & -3.098077 & -2.052056 & -3.024640 \\
\hline LNSEPETSA & -0.545160 & -2.028285 & -0.652449 & -1.985746 \\
\hline$\Delta$ NNOTOSA & $-9.294^{* * *}$ & $-9.279^{* * * *}$ & $-9.294^{* * * *}$ & $-9.266^{* * *}$ \\
\hline$\Delta$ NotSEPETSA & $-6.245^{* * *}$ & $-6.204^{* * * *}$ & $-6.252^{* * * *}$ & $-6.209^{* * *}$ \\
\hline$p$, olas1lik değerlerini ifade etmekte ve $* * *$ & $\mathrm{p}<0.01$ dir.
\end{tabular}

Tablo 4'te ilgili değişkenlerin düzey ve birinci farklar itibarıyla ADF ve PP test sonuçları yer almaktadır. Tablodan da görülebileceği gibi, hem ithal otomobil satışları hem de sepet kur değişkenleri için, gerek sabitli gerekse de sabitlitrendli durumlarda, "serilerin birim kökü vardır" boş hipotezi reddedilemez ve düzey değerleri itibarıyla birim köklü olduğu sonucuna varılır. Serilerin farkları alındığında serilerin durağan hale geldikleri, bir başka ifadeyle, serilerin I(1) oldukları görülmektedir.

Eşbütünleşme testleri ekonometride düzeyde durağan olmayan, ancak aynı dereceden durağan olan değişkenler arasında uzun dönemli ilişkinin tahmin edilmesine ve modellenmesine olanak sağlamaktadır. Buradan yola çıkarak Johansen eşbütünleşme testinin uygulanabilmesi için yapılması gereken; ilk olarak, vektör hata düzeltmedeki kalıntılarında, otokorelasyon, değişen varyans problemine yol açmayan ve hata terimlerinin normal dağılması varsayımını mümkün kılan optimal gecikme uzunluğunun (k) Vektör Otoregresif Model çerçevesinde belirlenmesidir (Aktaran: Küçükaksoy ark., 2015: 704). VAR modeli kurulduğunda çeşitli gecikme uzunluklarına ilişkin model seçim kriterleri değerleri Tablo 5'teki gibidir.

Tablo 5. Gecikme Uzunluğu

\begin{tabular}{ccccccc}
\hline Lag & LogL & LR & FPE & AIC & SC & HQ \\
\hline 0 & 66.84761 & NA & 0.000310 & -2.401763 & -2.328097 & -2.373353 \\
1 & 202.1480 & 255.5674 & $2.40 \mathrm{e}-06$ & -7.264740 & -7.043742 & -7.179510 \\
2 & 211.2299 & $16.48200^{*}$ & $1.99 \mathrm{e}-06^{*}$ & $-7.45296^{*}$ & $-7.08462^{*}$ & $-7.31090^{*}$ \\
3 & 212.0548 & 1.435902 & $2.24 \mathrm{e}-06$ & -7.335363 & -6.819700 & -7.136492 \\
4 & 216.6781 & 7.705446 & $2.20 \mathrm{e}-06$ & -7.358447 & -6.695452 & -7.102755 \\
5 & 220.1110 & 5.467258 & $2.26 \mathrm{e}-06$ & -7.337444 & -6.527117 & -7.024933 \\
6 & 220.4696 & 0.544552 & $2.60 \mathrm{e}-06$ & -7.202577 & -6.244919 & -6.833246 \\
7 & 222.1933 & 2.489778 & $2.86 \mathrm{e}-06$ & -7.118270 & -6.013279 & -6.692118 \\
8 & 224.8870 & 3.691441 & $3.05 \mathrm{e}-06$ & -7.069890 & -5.817567 & -6.586918 \\
\hline
\end{tabular}

Not: * işareti her bir model seçim kriteri için optimal gecikme uzunluğunu göstermektedir.

Tablodan, Logaritmik Olasılık Oranı (LR), Son Tahmin Hatası (FPE), Akaike Bilgi Kriteri (AIC), Schwarz Kriteri (SC) ve Hannan-Quinn Kriterleri (HQ)'nin hepsi için optimal uygun gecikme uzunluğunun iki olduğu görülmektedir.

Johansen ve Juselius (1990), tüm değişkenleri içsel olarak ele alan VAR modelini kullanarak, değişkenler arasında birden fazla eşbütünleşme ilişkisi olması durumunda bile kullanılabilecek bir eşbütünleşme testi geliştirmişlerdir. Bu çalışmada kullanılan değişkenlere ilişkin eşbütünleşme testi sonuçları Tablo 6'da ki gibidir. Hesaplanan iz istatistiği \%5 anlamlılık düzeyinde kritik değerden büyüktür. Yine, boş hipotezin olasılık değerine bakıldığında \%5'den daha küçük olduğu görülmektedir. Dolayısıyla $\mathrm{H}_{0}$ : Eşbütünleşme yoktur $(\mathrm{r}=0)$ hipotezi reddedilmekte ve $\mathrm{H}_{\mathrm{a}}$ : Eşbütünleşme vardır $(\mathrm{r}+1)$ hipotezi kabul edilmektedir. Buna göre, seriler arasında bir tane eşbütünleşme vektörü olduğu sonucuna varılmaktadır. Maksimum öz değer istatistiğine bakıldığında da aynı sonuca varılır. Bu bilgi ise, düzeyinde durağan olmayan değişkenlerle yapılacak ekonometrik tahminlerin katsayılarının ilişkiyi doğru yansıtacağını göstermektedir.

Tablo 6. Johansen Eşbütünleşme Testi Sonuçları

\begin{tabular}{ccccc}
\hline $\begin{array}{c}\text { Hipotezdeki } \\
\text { Koentegre } \\
\text { Vektör } \\
\text { Sayısı }\end{array}$ & Özdeğer & $\begin{array}{c}\text { İz } \\
\text { İstatistiği }\end{array}$ & $\begin{array}{c}\mathbf{0 . 0 5} \\
\text { Kritik } \\
\text { Değer }\end{array}$ & Olas.** \\
\hline yok & 0.328245 & 32.54015 & 25.87211 & 0.0064 \\
\hline en fazla 1 & 0.142442 & 9.066312 & 12.51798 & 0.1763 \\
\hline $\begin{array}{c}\text { Hipotezdeki } \\
\text { Koentegre } \\
\text { Vektör } \\
\text { Sayısı }\end{array}$ & Özdeğer & $\begin{array}{c}\text { Max- } \\
\text { Özdeğer } \\
\text { İstatistiği }\end{array}$ & $\begin{array}{c}\text { 0.05 Kritik } \\
\text { Değ. }\end{array}$ & Olas.** \\
\hline yok & 0.328245 & 23.47384 & 19.38704 & 0.0120 \\
\hline en fazla 1 & 0.142442 & 9.066312 & 12.51798 & 0.1763 \\
\hline
\end{tabular}

Değişkenler arasında uzun dönemli bir ilişkinin tespitinden sonra, bu ilişkinin şiddeti ve yönü; FMOLS, DOLS ve CCR tahmincileri kullanılarak tahmin edilmiştir. Tablo 7'de her üç yönteme ilişkin tahmin sonuçları yer almaktadır. Döviz kuruna ait katsayı FMOLS, DOLS ve CCR tahmincilerinde sırasıyla yaklaşık olarak; $-1.18,-1.23$ ve 1.17 çıkmıştır. $\mathrm{Bu}$ sonuç uzun dönemde döviz kurunda meydana gelecek \%1'lik bir artışın otomobil satışlarını; FMOLS'ye göre $\% 1.18$, DOLS'ye göre $\% 1.23$ ve CCR'ye göre \%1.17 oranında azaltacağını göstermektedir. Ayrıca, bu katsayının negatif ve birden büyük yani esnek olması teorik beklentilere uygundur.

Tablo 7. Uzun Dönem Katsayıları (Bağımlı Değişken LNOTOSA)

\begin{tabular}{lccc}
\hline $\begin{array}{l}\text { Değişkenler/ } \\
\text { Tahminciler }\end{array}$ & FMOLS & DOLS & CCR \\
\hline LNSEPETSA & $\begin{array}{c}-1.18217 * * * \\
(0.267514)\end{array}$ & $\begin{array}{c}-1.23265 * * * \\
(0.284158)\end{array}$ & $\begin{array}{c}-1.16823 * * * \\
(0.254785)\end{array}$ \\
\hline C & $\begin{array}{c}11.18527 * * * \\
(0.190279)\end{array}$ & $\begin{array}{c}11.18410 * * * \\
(0.200926)\end{array}$ & $\begin{array}{c}11.17557 * * * \\
(0.181617)\end{array}$ \\
\hline \multirow{2}{*}{ @TREND } & $\begin{array}{c}0.012824 * * * \\
(0.002024)\end{array}$ & $\begin{array}{c}0.013197 * * * \\
(0.002122)\end{array}$ & $\begin{array}{c}0.012721 * * * \\
(0.001932)\end{array}$ \\
\hline
\end{tabular}

Not: $p$, olasılık değerlerini ifade etmekte ve $* * * \mathrm{p}<0.01$ dir.

Her iki değişkenin de durağan oldukları varsayıldığında değişkenler arasındaki nedensellik ilişkisini tespit etmek için Granger (1987) nedensellik analizi yapılabilir. Granger nedensellik testi sonuçları Tablo 8'deki gibi bulunmuştur.

Tablo 8. Granger Nedensellik Testi

\begin{tabular}{lcc}
\hline Sıfır Hipotezi & F-İst. & Prob. \\
\hline $\begin{array}{l}\text { DLNSEPETSA, DLNOTOSA'nın } \\
\text { Granger nedeni değildir. }\end{array}$ & 10.3863 & 0.0002 \\
\hline $\begin{array}{l}\text { DLNOTOSA, DLNSEPETSA'nın } \\
\text { Granger nedeni değildir. }\end{array}$ & 1.18684 & 0.3130 \\
\hline
\end{tabular}

Granger nedensellik testi sonuçlarına bakıldığında, değişkenler arasında tek yönlü bir ilişki olduğu görülmektedir. Birinci denklemde sepet döviz kuru ithal otomobil satışlarının nedeni olarak açıklanmaktadır. Diğer yandan altta ise döviz kuru bağımlı değişken, ithal otomobil satışları bağımsız değişken olarak alınmıştır. Üstteki denklemde LNOTOSA'nın olasılık değerine bakıldığında sıfıra yakın olduğu görülmektedir. Dolayısıyla, temel hipotez olan "Döviz kuru ithal otomobil satışlarının Granger nedeni değildir" hipotezi $\% 5$ anlamlılık düzeyinde reddedilebilir. Nihayetinde döviz kuru ithal otomobil satışlarının nedeni olarak açıklanabilir. Alttaki denklemde ise durumun farklı olduğu görülmektedir. Buna göre otomobil satışları döviz kurunun sebebi değildir. 


\section{Sonuçlar ve Değerlendirmeler}

2011- Ocak ve 2016 Şubat aylarını kapsayan bu çalışmada, perakende otomobil satışları ile sepet döviz kuru arasındaki ilişki incelenmiştir. Öncelikle her iki seri de mevsimsellikten arındırılarak, birim kök testleri yardımıyla I(1) oldukları saptanmıştır. Değişkenlerin aynı düzeyde durağan olduklarının saptanmasından sonra, VAR modeli kurulmuş, bu model yardımıyla uygun gecikme uzunluğunun 2 olduğu belirlenmiştir. $\mathrm{Bu}$ gecikme uzunluğu dikkate alınarak eşbütünleşme testleri yapılmış ve döviz kuru ile ithal edilen otomobil satışları arasında bir uzun dönem ilişkinin var olduğu tespit edilmiştir. Nihayetinde, FMOLS, CCR ve DOLS tahmincileri aracılığıyla bu ilişkinin derecesi ve yönü araştırılmıştır. Yapılan analizler sonucunda her üç tahminci ile de birbirine yakın ve benzer sonuçlara ulaşılmıştır. Tahmin sonuçları, döviz kurunda meydana gelecek \%1'lik bir artışın ithal otomobil satışlarını uzun dönemde FMOLS, DOLS ve CCR tahmincilerine göre sırasıyla yaklaşık olarak; $\% 1.18, \% 1.23$ ve $\% 1.17$ oranlarında azaltacağını göstermektedir. $\mathrm{Bu}$ sonuçlar, ithal otomobil satışlarının teoriye uygun olarak döviz kuruna duyarlı $|e>1|$ olduğuna işaret etmektedir. Ayrıca bu esneklik katsayısı, Özçam (2015) tarafindan genel otomobil talebine yönelik olarak yapılan çalışmadaki esneklik katsayısı $(-1,071)$ ile benzerdir. Döviz kurunun katsayısı her iki çalışmada da negatif ve birden büyüktür. Nedensellik analizine gelindiğinde, sadece döviz kurlarından ithal otomobil satışlarına doğru bir ilişkinin olduğu görülmüştür.

2016 yılı verilerine göre Türkiye'nin toplam ithalatı 198,601 milyar dolardır. Toplam otomobil ithalatı ise 17,840 milyar dolar civarındadır. Bu rakamlar, Türkiye'nin toplam otomobil ithalatının toplam ithalatının \%8'ine tekabül ettiğini göstermektedir. Yine ülkemizin toplam ihracatı 2016 yılı itibarıyla 142,606 milyar dolardır. Toplam otomobil ihracatı ise 19,804 milyar dolar olmuştur. $\mathrm{Bu}$ da yaklaşık otomobil ihracatının toplam ihracatın \%13'üne tekabül ettiğine işaret etmektedir (OSD, 2017: 3). Bu veriler, kronik bir şekilde cari açık problemi yaşayan ülkemizde döviz kurunu olumsuz etkileyebilecek iç ya da diș bir ekonomi politikasının ya da döviz kuru dalgalanmalarının, otomobil ithalatının hacminin ve ithal otomobil talebinin döviz kuru esnekliğinin yüksek olması sebebiyle ödemeler bilançosu üzerine olumsuz etkiler doğurabileceğini göstermektedir. $\mathrm{Bu}$ ise özellikle iç ve dış para ve maliye politikası uygulamaları ve cari açığı azaltmaya yönelik politikalarda dikkat edilmesi gereken bir husus olarak ön plana çıkmaktadır. Yazarlar tarafından önümüzdeki dönemde, otomobil talebi ile ilgili bu önemli noktalardan yola çıkarak, Türkiye özelinde, otomobil talebinin belirleyicilerinin çok boyutlu olarak (gelir etkisi, tamamlayıcı ve ikâme ürünlerin etkileri, faiz ve enflasyon oranındaki değişimlerin ve finansal ve ticari bütünleşmenin etkileri vb.) analiz edilmesi düşünülmektedir.

\section{Kaynaklar}

Abu- Eisheh, Sameer. A. ve Mannering, F. L. (2002), "Forecasting Automobile Demand for Economies in Transition: A Dynamic Simultaneous-Equation System Approach", Transportation Planning and Technology, 25(4), 311-331.

Alper, C. Emre ve Mumcu-Serdar, Ayșe (2000), "Türkiye'de Otomobil Talebinin Tahmini”, Ekonomi ve Ekonometri Merkezi, Boğaziçi Üniversitesi.
Alper, C. E. ve Mumcu-Serdar, Ayşe (2007), "Interaction between Price, Quality and Country of Origin When Estimating Automobile Demand: The Case of Turkey", Applied Economics, 39(14), 1789-1796.

Bülbül, D.ve Orkunoğlu, I. F. (2009), “Türkiye'de Otomotiv Piyasasındaki Özel Tüketim Vergisi İndirimlerinin Maliye Sosyolojisi Açısından Analizi”, Sosyoekonomi, 10(10), 95-108.

Dickey, D. A. ve Fuller, W. A. (1981), "Likelihood Ratio Statistics for Autoregressive Time Series with A Unit Root", Econometrica, 49, 1057-1072.

Durkaya, M. ve Ceylan, S. (2006), "Vergi Gelirleri ve Ekonomik Büyüme", Maliye Dergisi, 150, 79-89.

Eken, Mehmet H. ve Mehmet Çiçek (2009), “Türkiye'de Otomotiv Sektöründeki Ürünlerin Kredilerle Finansmanının Satışlara Etkisi”, Maliye Finans Yazıları, 1(84), 61-77.

Engle, Robert F. ve Clive WJ Granger (1987), "Cointegration and Error Correction: Representation, Estimation and Testing", Econometrica, 55(2), 251-276.

Johansen, S. ve Juselius, K. (1990), "Maximum Likelihood Estimation and Inference on Cointegration with Applications to The Demand for Money", Oxford Bulletin of Economics and Statistics, $52,169-210$.

ODD (2016), "Pazar Perakende Aylık Satış Raporları", İnternet Adresi: www.odd.org, (Erişim Tarihi: 28.03.2016).

OSD (2016a), "Avrupa Toplam Otomotiv Sektör Analizi”, Şubat, 2016

OSD (2016b), "Otomotiv Sanayii Dış Ticaret Raporu”, 2016. 2017

OSD (2017), “Otomotiv Sanayii Dış Ticaret Raporu”, 1. Çeyrek,

Özçam, A. ve Dilek S. Ö. (2012), “A Review of Econometric Estimation of Consumer Demand for Automobiles and The Country of Origin (Coo) Effects", The Journal of Dokuz Eylul University, 27(1), 97-132.

Özçam, Ahmet (2014), "Should Before or After Tax Equilibria Point Elasticities Be Calculated When The Laffer Effect Is Considered in A Micro Market?", Journal of Economic Studies, 41(6), 754-770.

Özçam, A. ve Özçam, D. S. (2014), "Construction of SegmentBased Price Indexes in Turkish Automobile Market and Estimation of Varying Segment-Based Price Elasticities", Sütçü Imam Üniversitesi I.I.I.B.F. Dergisi, 4(1), 35-54.

Özçam, A. ve Özçam, D. S. (2015), "Business Cycles, Estimation of Demand for Automobiles in Turkey and Calculation of Time-Varying Price Elasticities", İstanbul Ticaret Üniversitesi Sosyal Bilimleri Dergisi, 14(27), 89-110.

Küçükaksoy, İ; Çiftçi, İ ve Özbek, R. İ. (2015), "İhracata Dayalı Büyüme Hipotezi: Türkiye Uygulaması", Çankırı Karatekin Üniversitesi İ.̇.B.F. Dergisi, 5(2), 691-720.

Madden, Garry (1988), "An Econometric Model of Australian Passenger Automobile Demand: A Segmented Markets Approach", Economic Analysis and Policy, 18(1), 53-69.

Mehmood, B. ve Shadid A. (2014), "Aviation Demand and Economic Growth in The Czech Republic: Cointegration Estimation and Causality Analysis", Statistika, 94(1), 54-63.

Mthembu, Mandla S. (2015), "The Impact of Education Expenditure, Tertiary Enrollment and Innovation on Economic Growth in South Africa", University of Zululand, Doktora Tezi.

Park, Joon Y. (1992), "Canonical Cointegrating Regressions", Econometrica: Journal of the Econometric Society, 60(1), 119-143.

Phillips, P. CB. ve Hansen, B. E. (1990), "Statistical Inference in Instrumental Variables Regression with I (1) Processes", The Review of Economic Studies, 57, 99-125. 
Phillips, P. CB. ve Perron, P. (1988), "Testing for A Unit Root in Time Series Regression", Biometrica, 75(2), 335-346.

Refaei, R. ve Morteza S. (2015), "Official Development Assistance and Economic Growth in Iran", International Journal of Management, Accounting and Economics, 2(2), 125-135.

Saikkonen, Pentti (1992), "Estimation and Testing of Cointegrated Systems by an Autoregressive Approximation". Econometric Theory, 8(1), 1-27.

Stock, J. H. ve Watson, M. W. (1993), “A Simple Estimator of Cointegrating Vectors in Higher Order Integrated Systems", Econometrica: Journal of the Econometric Society, 61(4), 783-820.

TCMB (2016), "Elektronik Veri Dağıtım Sistemi”, İnternet Adresi: www.tcmb.gov.tr. (Erişim Tarihi: 28.03.2016).

TEPAV (2013), “Dünya ve Türkiye Otomativ Sektörü”, 2013.

Wang, Q. ve Wu, Na (2012), "Long-Run Covariance and Its Applications in Cointegration Regression", The Stata Journal, 12(3), 5 